\title{
Optimal Regulation of the Balance between Productivity and Overwintering of Perennial Grasses in a Warmer Climate
}

\author{
Åshild Ergon \\ Department of Plant Sciences, Faculty of Biosciences, Norwegian University of Life Sciences, P.O. Box 5003, \\ N-1432 Ås, Norway; ashild.ergon@nmbu.no \\ Academic Editors: John W. Forster and Kevin F. Smith \\ Received: 2 January 2017; Accepted: 21 February 2017; Published: 23 February 2017
}

\begin{abstract}
Seasonal growth patterns of perennial plants are linked to patterns of acclimation and de-acclimation to seasonal stresses. The timing of cold acclimation (development of freezing resistance) and leaf growth cessation in autumn, and the timing of de-acclimation and leaf regrowth in spring, is regulated by seasonal cues in the environment, mainly temperature and light factors. Warming will lead to new combinations of these cues in autumn and spring. Extended thermal growing seasons offer a possibility for obtaining increased yields of perennial grasses at high latitudes. Increased productivity in the autumn may not be possible in all high latitude regions due to the need for light during cold acclimation and the need for accumulating a carbohydrate storage prior to winter. There is more potential for increased yields in spring due to the availability of light, but higher probability of freezing events in earlier springs would necessitate a delay of de-acclimation, or an ability to rapidly re-acclimate. In order to optimize the balance between productivity and overwintering in the future, the regulation of growth and acclimation processes may have to be modified. Here, the current knowledge on the coordinated regulation of growth and freezing resistance in perennial grasses is reviewed.
\end{abstract}

Keywords: CBF; climate change; cold acclimation; de-acclimation; freezing; growth; light; photoperiod; seasonality; stress; temperature; winter survival

\section{Introduction}

Changes in atmospheric $\mathrm{CO}_{2}$ concentration, temperature, and precipitation patterns are expected to affect plant productivity in a complex manner due to a set of mechanisms and interactions at different scales from leaf to agro-ecosystem [1]. In regions or periods where water availability is sufficient, elevated atmospheric $\mathrm{CO}_{2}$ concentrations and higher temperatures can potentially increase growth rates of many plant species, including $\mathrm{C}_{3}$ grasses and forage legumes, and thus increase grassland productivity [2]. In addition to this direct effect of temperature and $\mathrm{CO}_{2}$ concentration, cool regions with non-productive winters are likely to have longer thermal growing seasons (often defined as the part of the year when the daily mean temperature exceeds $5^{\circ} \mathrm{C}$ ), with earlier springs and later autumns. For example, in Finland, where the annual mean temperature has most likely increased by at least $2{ }^{\circ} \mathrm{C}$ during the last 150 years [3], the thermal growing season was predicted to become one to three months longer by the end of the century as compared to the period 1971-2000 [4]. Such extended growing seasons are expected to contribute to the increase in annual grassland yields in temperate climates [5-9]. Although the prediction models used so far account for drought limitations on growth, they do not account for possible effects of plant survival during seasonal stresses. However, a recently developed model, which incorporates both the cold acclimation process in autumn and winter survival, will improve predictions for high latitudes in this respect [10]. 
Perennial grasses have the potential to utilize the light energy over a larger part of the year than most annual crops, but should survive and produce biomass for several years. The annual recurrent periods of winter stresses or summer droughts in some regions have led to the evolution of seasonal acclimation and de-acclimation processes regulating the level of resistance to seasonal stresses [11-13]. These processes, which are largely regulated by temperature and photoperiod, correlate with changes in growth, development, and dormancy status [13-15], and latitudinal clines in growth responses to temperature and photoperiod have been described [16]. Acclimation and de-acclimation are associated with cessation and resumption of leaf growth, respectively, suggesting a classical growth-stress survival trade-off [17] in the adaptation to seasonal stresses [15]. It is important to note, though, that cessation of leaf growth does not always mean cessation of biomass accumulation, but rather a shift in allocation of photosynthates from leaf blades to newly formed tillers, roots, and storage tissues [18]. Although some perennial grasses have been shown to possess summer endodormancy of shoot meristems $[12,14]$, the existence of winter endodormancy has not been demonstrated to my knowledge, although perennial grasses are obviously ecodormant during cold winter periods. Instead, the shoot meristems that are formed during the latter part of summer and/or during autumn (variations between species) are more or less unresponsive to long day-induction of reproductive development. They gradually become responsive during weeks of low temperature (vernalization), a process which occurs faster in short than in long photoperiods [19].

Winter survival of perennial grasses can be measured directly at the individual plant level, but is frequently measured at sward level as the relative recovery in spring, a measure which also encompasses rate of tiller survival, and earliness and rate of regrowth. Winter survival is an extremely complex trait being the result of both an acclimation process and responses to numerous types of stresses that plants encounter and must endure during winter and early spring [20]. The term "cold acclimation" refers to the development of resistance to freezing stress. Temperature is a major environmental factor controlling cold acclimation and cold de-acclimation in perennial grasses, although light factors are also of importance. Low temperature induces not only freezing resistance, but also resistance to other winter stresses, such as ice encasement/anoxia [21], and fungal pathogens (snow molds) [22,23], which, depending on climatic conditions, may have a much stronger influence on winter survival than freezing [20].

Temperatures are increasing in most regions of the world [24,25], but the annual variation in photoperiod will remain the same. We will therefore have new seasonal combinations of temperature and photoperiod in the future, particularly at high latitudes, where photoperiod changes dramatically during the course of a year. This may lead to mismatches between annual cycles of growth, development, and stress resistance. In order to utilize the new seasonal patterns to maximize the production of biomass from perennial grasses, while maintaining sufficient survival through stressful parts of the year, we need species and varieties with temperature and photoperiod responses conferring an annual growth pattern that optimizes the balance between growth and survival. This review aims to describe the physiological and genetic factors that determine the balance between the productivity and overwintering of perennial grasses in the longer thermal growing seasons expected at high latitudes in the future.

\section{Can We Increase Autumn Productivity at High Latitudes?}

Autumn-extended thermal growing seasons, combined with higher atmospheric $\mathrm{CO}_{2}$ concentrations, have the potential to increase the productivity of perennial grasses in the autumn [6-9]. However, since the annual variation in temperature lags behind the annual variation in photoperiod, there is less light in autumn than at comparable temperatures in spring (Figure 1). Therefore, light availability may limit the utilization of the extended growing season in autumn [26,27]. Insufficient light not only limits growth rates, but can also prevent proper acclimation to several types of winter stress [28-33]. Light factors during the cold acclimation period can affect the freezing tolerance of herbaceous overwintering plants in several ways [34,35]. Firstly, a certain irradiance combined 
with low temperature increases photosystem II (PSII) excitation pressure, which is a signal leading to the development of freezing resistance [36-40]. Secondly, short photoperiod and low red to far red light (R:FR) ratio can interact with low temperature to stimulate the development of freezing resistance [41-44]. Thirdly, irradiance is the energy source for the accumulation of carbohydrates with a functional role in freezing resistance [40]. In addition, irradiance is the energy source for the accumulation of carbohydrate reserves needed for maintenance and stress responses during winter, as well as for early regrowth in spring.

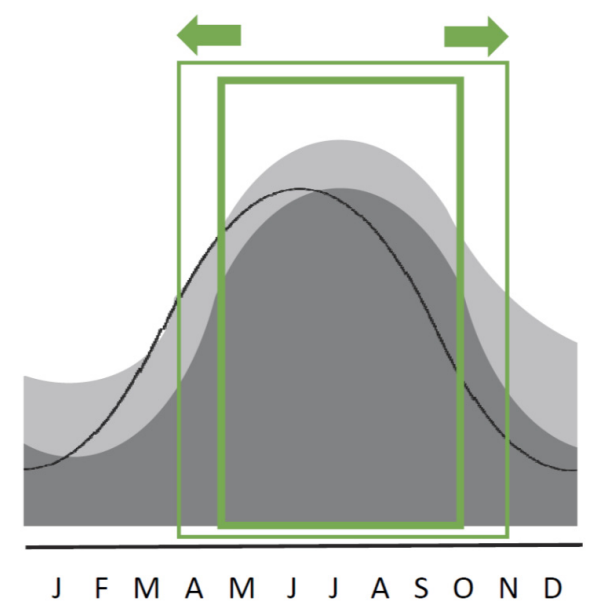

Figure 1. The thermal growing season and annual variation in photoperiod and temperature at a northern latitude. With higher temperatures in the future (light grey area), the thermal growing season will extend in both ends (outer green box) as compared to today (dark grey area and inner green box). The annual changes in temperature (grey area) lags behind the annual changes in photoperiod (black line). With higher temperatures in the future, but the same photoperiod variation as today, we will have new combinations of temperature and photoperiod.

In order to obtain high productivity over several years, a high rate of winter survival and vigorous spring regrowth is necessary, and therefore increased autumn productivity through an extended growing season can only be sustainably achieved if there is enough light during the delayed cold acclimation period. The required levels of acclimation and of stored carbohydrate reserves depend on the severity of the prevailing stresses and on the magnitude of the net photosynthetic deficit that might accumulate during winter, both which can vary greatly from year to year, and which do not necessarily diminish with climate change [20]. There are, in theory, two contrasting options for genetic adaptation to autumn-extended thermal growing seasons at high latitudes: either utilize the extended growing period and cold acclimate later in the autumn, but at the same temperature as today, or cease leaf growth and cold acclimate at the same photoperiod as today, but at higher temperatures (Figure 2). Which option is the best one with regard to optimization of long-term yield would depend on the amount of light needed for sufficient cold acclimation and for sufficient accumulation of carbohydrates. The relative importance of temperature and light factors in cold acclimation and cessation of leaf growth in perennial grasses is not very well characterized, neither are the interactions between temperature and light. It has been suggested that plants adapted to the extreme north rely more on photoperiod than temperature for timing of cold acclimation and cessation of leaf growth than other plants, and that such photoperiodic control will be of increasing importance in southern Scandinavia in the future [32]. The genetic association between cold acclimation and cessation of leaf growth is also not well characterized. The negative correlation between accumulation of carbohydrate reserves and production of harvestable biomass (i.e., assimilate partitioning) is difficult to get around. The association between leaf growth and cold acclimation may have a regulatory cause (discussed 
below) rather than a physiological cause, and thus it may be possible to break this association through breeding, as has been suggested for alfalfa (Medicago sativa L.) [45-47].

When considering the possibilities for adaptation to autumn-extended thermal growing seasons, it would be relevant to know: (1) to what extent do perennial grasses depend on PSII excitation pressure for induction of cold acclimation and how much light is required for this? (2) how much carbohydrate reserves are needed, and how much light is required after cessation of leaf growth, if any, to build this storage? and (3) how are the different aspects of growth, allocation of photosynthates, and cold acclimation regulated by environmental and genetic factors?

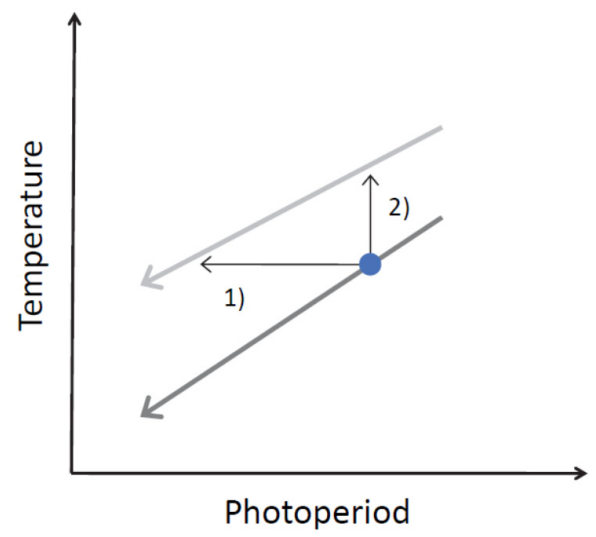

Figure 2. What is the optimal timing of cold acclimation and cessation of leaf growth in autumn? The grey arrows indicate the change in photoperiod and temperature during current (dark grey) and future (light grey) autumns. The timing of cold acclimation and cessation of leaf growth (blue dot) in the future climate could occur (1) at the same temperature as today, but shorter photoperiods (horizontal black arrow), or (2) at the same photoperiod as today, but warmer temperatures (vertical black arrow). Option (1) would allow higher biomass production, but cold acclimation and accumulation of sufficient carbohydrate reserves might be compromised by limited light energy.

\subsection{The Role of Light in Signalling Mechanisms Inducing Cold Acclimation}

Low temperature limits the rates of enzymatic reactions of photosynthesis more than the rates of electron transfer reactions in the light harvesting systems. As a result, low temperature in light creates an energy imbalance in the photosystems, leading to a change in the redox state of photosynthetic electron-transport components and a high excitation pressure of PSII [36-38]. The altered photosystem redox state functions as an irradiance-dependent cold sensor. As a result of the PSII over-excitation, reactive oxygen species (ROS) are generated, and these may act in signaling pathways leading to the expression of genes involved in freezing resistance $[48,49]$ as well as a compact growth habit in overwintering herbaceous plants $[36,37,50-53]$. This mechanism of sensing cold might become less efficient if the cold acclimation period is shifted to a later time in autumn in the future, particularly at high latitudes, were irradiance levels are rapidly declining during that time of year. There are, however, also other mechanisms by which plants may sense low temperature and initiate development of freezing resistance, such as changes in membrane rigidity, temperature-dependent histone-DNA interactions, and conformational changes of RNA and protein structure $[48,54]$. These mechanisms may increase in importance if the cold acclimation period is postponed to a later time of year in the future.

Overwintering plant species have different strategies to handle the potentially damaging excess energy associated with elevated PSII excitation pressure [37-39]. In winter wheat and winter rye the photosynthetic capacity is upregulated during cold acclimation (photochemical quenching, $q_{p}$ ), ensuring utilization of the energy available from the light harvesting complexes. Compared to winter cereals, spring cereals exhibit less photosynthetic acclimation, rely more on dissipation of 
excess energy by release of heat (non-photochemical quenching, NPQ) and less on $\mathrm{q}_{\mathrm{p}}$, and are more sensitive to both photoinhibition and freezing [55-57]. In the perennial grasses meadow fescue (Schedonorus pratensis Huds., syn. Festuca pratensis Huds.), perennial ryegrass (Lolium perenne L.), and timothy (Phleum pratense L.), NPQ appears to be a more important mechanism of photosynthetic acclimation to cold than $\mathrm{q}_{p}$ [58-60]. In the less freezing resistant Italian ryegrass (L. multiflorum $\mathrm{L}$.), $\mathrm{q}_{\mathrm{p}}$ increased after cold acclimation and NPQ decreased, while a part of meadow fescue chromosome 4 introgressed into Italian ryegrass was associated with higher cold-induced NPQ and freezing resistance [59]. However, it appears that both NPQ and $q_{p}$ take place and that the relative importance of these two mechanisms vary among genotypes. For example, Kosmala et al. [61] found higher amounts of some proteins involved in photosynthetic carbon metabolism in a freezing resistant genotype of meadow fescue than a less tolerant genotype, suggesting a role of $\mathrm{q}_{\mathrm{p}}$. Moreover, the relative magnitudes of NPQ and $q_{p}$ may be related to the carbohydrate status of the plant, with higher $\mathrm{q}_{\mathrm{p}}$ in plants with less stored carbohydrates. Selection of photochemical quenching rather than non-photochemical quenching as a mode of photoacclimation to cold appears to be favorable as some of the accumulating photosynthates could either support survival during a long winter or be converted into forage production the following spring.

\subsection{The Role of Photosynthates in Winter Survival}

In temperate perennial grasses, simple carbohydrates accumulate during cold acclimation and most of these are converted into fructans, which accumulate mainly in the basal part of the shoot $[18,62,63]$. In regions with a long winter, a storage of organic reserves, particularly carbohydrates, are necessary for maintenance respiration, stress responses, and early spring regrowth. In addition, carbohydrates have specific roles as osmolytes and protectants of cellular components [13,40], and winter survival ability is often associated with a higher concentration of both simple sugars and fructans in the basal parts of the shoot attained during cold acclimation [64-67]. As described above, winter cereals maintain $\mathrm{CO}_{2}$-fixation rates at low temperatures due to photosynthetic acclimation, a mechanism, which combined with restrictions on leaf growth, ensures that a storage of carbohydrates is accumulating. Elevated atmospheric $\mathrm{CO}_{2}$ concentrations may affect cold acclimation and winter survival in several ways. For example, higher $\mathrm{CO}_{2}$ concentrations could inhibit the generation of a PSII excitation pressure signal or enhance the accumulation of carbohydrate reserves. The few studies of perennial grasses have contrasting results regarding the impact of elevated $\mathrm{CO}_{2}$ on freezing resistance $[30,68,69]$.

The amount of carbohydrate reserves that have to be stored in order to ensure winter survival depends on several factors. A general assessment is that a larger carbohydrate storage will be required in areas were photosynthesis is limited for a long period due to low irradiance, thick snow cover, freezing temperatures, or dying leaf blade tissues, meaning that the plants must draw on stored reserves. Obtaining as high annual yields as possible while maintaining tiller survival is a fine-tuned balance between the allocation of autumn photosynthates into leaf growth versus storage. The potential for utilizing light energy in longer growing seasons (beyond the autumn equinox) for increased autumn yield, rather than for storage, may therefore be highest at lower latitudes and diminish as we move towards higher latitudes with darker autumns and longer winters. Interestingly, during a relatively mild winter without snow cover (approximate average temperature $2{ }^{\circ} \mathrm{C}$ ) at $61^{\circ}$ latitude in western Norway, timothy and perennial ryegrass both accumulated carbohydrates in the shoot base during winter, and more so in the most winter hardy species/cultivars [62,70]. Although this could be due to reallocation within the plant, it is known that photosynthesis can operate at very low temperatures around or even below $0{ }^{\circ} \mathrm{C}[71,72]$. This result indicates that at this latitude, there may be possibilities for maintaining or even accumulating a carbohydrate storage during such mild winters. It is, however, a prerequisite that the leaf tissue survives, and it is likely that there will be strong effects of the timing of the last defoliation, as the amount of new leaf area developed prior to the cessation of leaf growth is critical. Predictions of ideotypes for different regions in a future climate [73] could aid breeding efforts 
to achieve the optimum balance between allocation of photosynthates to leaf growth versus storage. The severity of winter conditions vary greatly from year to year, and plants need to be designed to be able to survive winters that are harsher than the average winter. In any case, when it comes to photosynthates, these are possibly better invested in rapid regrowth in spring, when light conditions are very good, than in autumn growth.

\subsection{Regulation of Leaf Growth versus Cold Acclimation}

In herbaceous overwintering plants, leaf growth inhibition in response to low temperature is not simply a result of lower metabolic rates, but an actively regulated process, which is coordinated with changes in carbon metabolism [74]. Concomitantly with the development of freezing resistance at low temperatures, winter rye, winter wheat, Arabidopsis thaliana, and Brassica napus develop a dwarf phenotype with shorter, thicker leaves that have a distinct anatomy and high concentrations of proteins and carbohydrates [75]. In addition, these species upregulate their photosynthetic capacity to compensate for the slower rates of enzymatic reactions at low temperature, and accumulate carbohydrates in storage organs. Unlike winter cereals, spring cereals do not develop a dwarf phenotype during cold acclimation, do not upregulate the photosynthetic capacity to the same level, and are not able to attain the same level of freezing resistance $[57,75]$.

In experiments with several perennial forage grasses exposed to different photoperiods, but the same total amount of photosynthetic active radiation (PAR), it was shown that long photoperiods stimulate increased specific leaf area (SLA, leaf area per unit of leaf dry weight) and increased dry matter production, and conversely, that short photoperiods result in lower SLA and productivity [76-78]. Short photoperiod also stimulates tiller formation in perennial forage grasses [79,80], a process which likely improves the potential for spring productivity. Interestingly, at short photoperiods, low irradiance levels, and relatively high autumn temperatures $\left(12{ }^{\circ} \mathrm{C}\right)$, a stimulation of leaf elongation was observed in perennial ryegrass and timothy [33], indicating that when the temperature is not low enough, the shade avoidance syndrome [81] can override the photoperiod response of leaf elongation. This could possibly become a problem during mild, rainy autumns at high latitudes in the future.

C-REPEAT BINDING FACTORs (CBFs) appear to be central in the coordinated regulation of leaf growth and freezing tolerance in response to low temperature [34,74] (Figure 3). CBF transcription factors upregulate whole sets of genes encoding proteins with direct functions in freezing resistance [82]. Temperate grasses have a large number of $C B F$ genes, which are differentially expressed in response to various environmental signals [82-88]. Exactly which of the $C B F$ genes has the largest influence on freezing resistance appears to vary between species, genetic background, and/or environment [89-92]. One of the three CBFs in A. thaliana is upregulated by PSII excitation pressure, redox state of the plastoquinon pool, and ROS signaling [49]. However, barley mutants with an impaired chloroplast development had normal cold-induced expression of at least some $C B F s$, indicating that their expression does not depend solely on a signal generated in the chloroplasts [93]. Indeed, Marozsán-Tóth et al. [85] showed that some CBFs in barley were regulated through $\mathrm{Ca}^{2+}$ signaling. Short photoperiods and low R:FR ratios can interact with temperature to induce freezing resistance in A. thaliana, and this effect is mediated by the circadian clock through its control of $C B F$ expression [42,43]. In wheat and barley, low R:FR ratios upregulate expression of CBF14 as well as freezing resistance [44], and in meadow fescue CBF6 expression is affected by interactions between temperature, light quality, and irradiance [94]. In A. thaliana, CBFs can down-regulate leaf growth by down-regulating the content of gibberellic acid (GA), thereby allowing the accumulation of DELLA proteins which inhibits growth, and in addition increases freezing resistance by a reduction of ROS $[95,96]$. CBFs can also enhance photosynthetic capacity in B. napus $[56,97,98]$, and may therefore play a role in photosynthetic quenching and maintenance of biomass accumulation at low temperatures. All this points to the $C B F$ family of transcription factors as integrators of many different adaptive responses to autumn conditions leading to winter survival. 


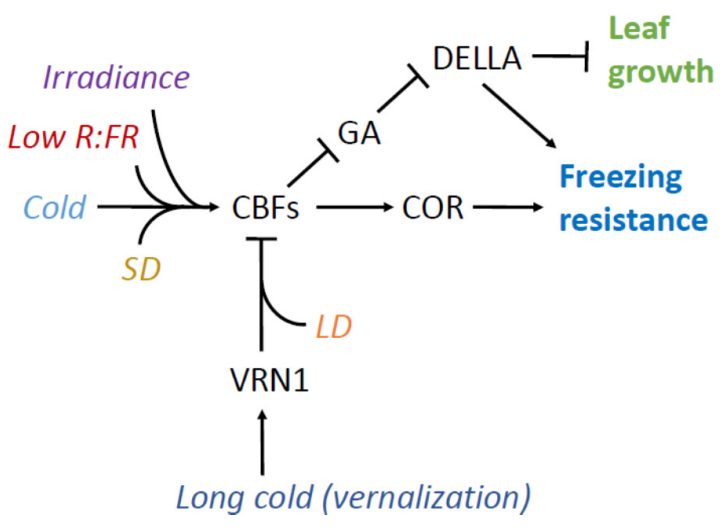

Figure 3. Putative model showing the central role of CBF transcription factors in coordinating freezing resistance and leaf growth in response to temperature and light. Cold induces expression of CBFs, which are important in the development of freezing resistance through the induction of the CBF regulon of cold-induced genes (here collectively indicated with COR), and also play a role in down-regulation leaf growth via gibberellic acid (GA). Short days (SD), irradiance, and low red to far red light-ratio (R:FR), can take part in the induction of CBFs. Prolonged cold leads to a gradual increase in VRN1 transcripts. VRN1 can down-regulate CBFs and freezing resistance, particularly in long days (LD). In temperate grasses there are around $20 C B F$ genes which are likely to have partly differentiated roles.

\section{Can We Increase Spring Productivity at High Latitudes?}

Unlike the situation in autumn, it is not light availability, but temperature, which is currently limiting biomass production in spring at high latitudes (Figure 1). Thus, there is a potential to utilize an earlier thermal growing season in the future. However, with the growing season starting earlier in the year, and possibly before the spring equinox, the day-night temperature amplitude and the probability of night frost or longer freezing periods increases. For example, the probability of spring frost damage was predicted to increase in the western part of the Nordic area in 2040-2065 as compared to 1960-1990 [5].

In general, exposure to higher temperatures in spring results in stimulation of growth and at the same time, loss of freezing resistance (de-acclimation) [20]. There are several reports describing de-acclimation and re-acclimation responses in perennial grass species [99-105], and some of them also report a negative association between freezing resistance and leaf growth during the de-acclimation period. In cereals, it has been shown that both freezing resistance and expression of cold-induced genes are down-regulated in shoot base tissue when the vernalization requirement is saturated, but before any development of the apex is visible in the microscope [106-108]. There is an interaction between vernalization and photoperiod on de-acclimation. In cultivars with a long day requirement for flowering, the negative effect of vernalization on freezing resistance is stronger when plants are vernalized under long days than under short days, whereas vernalization- and photoperiod-insensitive cultivars are not able to develop much freezing resistance at all [109-112]. Also, plants vernalized and de-acclimated under long days are often found to be less able to re-acclimate [113,114]. Vernalization not only enhances de-acclimation, as well as competency to flower in response to long photoperiod in a large number of perennial grass species [19], but also increases the rate of leaf expansion, specific leaf area, and photosynthetic rate of perennial ryegrass leaves developed after transfer to $15^{\circ} \mathrm{C}$, particularly under long photoperiods [115].

In order to utilize more of the spring light for increased productivity, it would be necessary to grow plants that are capable of maintaining freezing tolerance during early spring growth, and/or able to rapidly re-acclimate upon demand. In this context, it would be desirable to have a better understanding of (1) how do temperature, vernalization, and photoperiod together control leaf growth and freezing resistance in spring? and (2) which mechanisms govern rapid re-acclimation after de-acclimation, and to which extent do these function in growing plants? 


\subsection{Regulation of Leaf Growth versus Freezing Resistance in Spring}

$V R N 1$, an inducer of the transition to generative development in cereals and other temperate grass species, is gradually up-regulated during vernalization [116,117]. Several studies indicate that there is a negative association between expression level of $V R N 1$ and the expression of cold-induced genes and freezing resistance. Using near-isogenic lines of wheat and barley, and a T. monococcum deletion mutant, it was shown that, under $16 \mathrm{~h}$ photoperiod, the VRN1 locus controls expression of VRN1, COR14B, and other cold induced-genes [106-108,112,118]. High expression levels of VRN1 were associated with the down-regulation of cold-induced genes and freezing resistance. From these studies, however, it is not entirely clear whether it is VRN1 itself, or very closely linked genes, that is responsible. However, using a transgenic approach combined with chromatin immunoprecipitation sequencing and RNA sequencing, Deng et al. [119] showed that in barley grown at $16 \mathrm{~h}$ photoperiod, VRN1 binds to the promoter of several CBF genes. After short-term cold exposure, when the expression level of $V R N 1$ is still very low, Oliver et al. [120] found similar kinetics in the initial transcription of VRN1 and COR14B upon cold exposure (24 h) in barley. Under short photoperiods, high COR14B expression or positive correlation between expression of $V R N 1$ and COR14B remained after long-term cold treatment in T. monococcum [112], barley [121], and meadow fescue [105]. COR14B is induced by $C B F$ s, and barley $V R N 1$ also has a putative $C B F$ binding site in its promoter [122]. Oliver et al. [107] therefore suggested that VRN1 and COR14B may be regulated by similar mechanisms in early cold acclimation, possibly through the action of CBF transcription factors. Several studies show that CBF6 and COR14B are down-regulated in cereals and meadow fescue by prolonged cold, but only under long photoperiods [105]. Taken together, these results suggest that VRN1 and the CBF regulon are co-regulated during cold acclimation of temperate grasses and as long as photoperiods are short, but that VRN1 down-regulates CBFs when photoperiods become long (Figure 3). This is a possible explanation for the interaction between vernalization and photoperiod during de-acclimation in temperate grasses. Also, given that CBFs can inhibit leaf growth via GA and DELLA proteins [34], the regulatory effect of VRN1 on CBF expression may explain the effects of vernalization on leaf growth and photosynthetic activity observed by Stapleton and Jones [115], and also its interaction with photoperiod.

\subsection{Is Re-Acclimation in Spring Different from Cold Acclimation in Autumn?}

Under controlled conditions, the re-acclimation of temperate grasses differs somewhat from the initial cold acclimation. For example, carbohydrates did not accumulate to the same extent during re-acclimation as during initial cold acclimation in winter wheat [114], and several cold induced genes upregulated by cold acclimation in meadow fescue were not upregulated during re-acclimation [105]. The mechanisms behind these differences are not known, but are likely to be related to a coordinated regulation of growth and freezing tolerance as described in Section 2.3. In the field, re-acclimation may also be inhibited if plants are exhausted from carbohydrate reserves or devoid of functional leaf area. Re-acclimation at a time when spring growth has been initiated may be provided by other mechanisms than those employed during initial cold acclimation in the autumn. For example, while expression of COR14B could explain some of the variation in freezing resistance in de-acclimated meadow fescue, $C R 7$ was, unlike $C O R 14 B$, significantly upregulated by re-acclimation and could explain some of the variation in freezing resistance after re-acclimation [105].

\section{Conclusions}

The expected prolonged growing season in future autumns can probably be utilized for higher autumn productivity in some areas, but in areas were photosynthesis is prohibited during long winters, such as at high latitudes, areas with a deep long-lasting snow cover, or with severe stresses killing leaf blades, this may not be possible due to the need for storage carbohydrates. There is a larger potential for utilizing the earlier springs to increase productivity in such areas, but it will be necessary with 
varieties that maintain some level of freezing resistance and re-acclimation ability also during early spring regrowth.

The many $C B F$ genes in perennial grasses, which are differentially regulated and probably have different functions, could possibly be utilized in developing varieties that combine some autumn productivity with cold acclimation. Similarly, a possibility of at least partly breaking the association between growth, de-acclimation, and loss of re-acclimation ability in spring may lay in playing with alleles of the various $C B F$ genes and their differential functions. The interaction between temperature and light factors, particularly photoperiod, on $C B F$ regulation is critical in this respect. An improved understanding of the specific functions of the various $C B F$ genes-how they are regulated and which parts of the $C B F$ regulon they control, as well as an overview of allelic variation-could aid in the development of perennial grass varieties with an optimal balance between growth and perennial persistence under future climates.

Conflicts of Interest: The author declares no conflict of interest.

\section{References}

1. Hatfield, J.L.; Prueger, J.H. Agroecology: Implications for plant response to climate change. In Crop Adaptation to Climate Change; Yadav, S.S., Redden, R.J., Hatfield, J.L., Lotze-Campen, H., Hall, A.E., Eds.; Wiley-Blackwell: Chichester, UK, 2011; pp. 27-43.

2. Soussana, J.-F.; Lüscher, A. Temperate grasslands and global atmospheric change: A review. Grass For. Sci. 2007, 62, 127-134. [CrossRef]

3. Mikkonen, S.; Laine, M.; Mäkelä, H.M.; Gregow, H.; Tuomenvirta, H.; Lahtinen, M.; Laaksonen, A. Trends in the average temperature in Finland, 1847-2013. Stoch. Environ. Res. Risk Assess. 2015, 29, 1521-1529. [CrossRef]

4. Ruosteenoja, K.; Räisänen, J.; Pirinen, P. Projected changes in thermal seasons and the growing season in Finland. Int. J. Climatol. 2011, 31, 1473-1487. [CrossRef]

5. Höglind, M.; Thorsen, S.M.; Semenov, M.A. Assessing uncertainties in impact of climate change on grass production in Northern Europe using ensembles of global climate models. Agric. For. Meteorol. 2013, 170, 103-113. [CrossRef]

6. Jing, Q.; Bélanger, G.; Qian, B.; Baron, V. Timothy yield and nutritive value under climate change in Canada. Agron. J. 2013, 105, 1683-1694. [CrossRef]

7. Jing, Q.; Bélanger, G.; Qian, B.; Baron, V. Timothy yield and nutritive value with a three-harvest system under the projected future climate in Canada. Can. J. Plant Sci. 2014, 94, 213-222. [CrossRef]

8. Thivierge, M.-N.; Jégo, G.; Bélanger, G.; Bertrand, A.; Tremblay, G.F.; Rotz, C.A. Predicted yield and nutritive value of an alfalfa-timothy mixture under climate change and elevated atmospheric carbon dioxide. Agron. J. 2016, 108, 1-19. [CrossRef]

9. Graux, A.-I.; Bellocchi, G.; Lardy, R.; Soussana, J.-F. Ensemble modelling of climate change risks and opportunities for managed grasslands in France. Agric. For. Meteorol. 2013, 170, 114-131. [CrossRef]

10. Höglind, M.; van Oijen, M.; Cameron, D.; Persson, T. Process-based simulation of growth and overwintering of grassland using the BASGRA model. Ecol. Model. 2016, 335, 1-15. [CrossRef]

11. Laude, H.M. The nature of summer dormancy in perennial grasses. Bot. Gaz. 1953, 114, 282-292. [CrossRef]

12. Volaire, F.; Norton, M. Summer dormancy in perennial temperate grasses. Ann. Bot. 2006, 98, 927-933. [CrossRef] [PubMed]

13. Preston, J.C.; Sandve, S.R. Adaptation to seasonality and the winter freeze. Front. Plant Sci. 2013, 4, 167. [CrossRef] [PubMed]

14. Norton, M.R.; Volaire, F.; Lelièvre, F.; Fukai, S. Identification and measurement of summer dormancy in temperate perennial grasses. Crop Sci. 2009, 49, 2347-2352. [CrossRef]

15. Gillespie, M.; Volaire, F.A. Are winter and summer dormancy symmetrical seasonal adaptive strategies? The case of temperate herbaceous perennials. Ann. Bot. 2017, 119, 311-323. [CrossRef] [PubMed]

16. Cooper, J.P. Climatic Variation in Forage Grasses. I. Leaf Development in Climatic Races of Lolium and Dactylis. J. Appl. Ecol. 1964, 1, 45-61. [CrossRef]

17. Sibly, R.M.; Calow, P. A life-cycle theory of responses to stress. Biol. J. Linn. Soc. 1989, 37, 101-116. [CrossRef] 
18. Hisano, H.; Kanazawa, A.; Yoshida, M.; Humphreys, M.O.; Iizuka, M.; Kitamura, K.; Yamada, T. Coordinated expression of functionally diverse fructosyltransferase genes is associated with fructan accumulation in response to low temperature in perennial ryegrass. New Phytol. 2008, 178, 766-780. [CrossRef] [PubMed]

19. Heide, O.M. Control of flowering and reproduction in temperate grasses. New Phytol. 1994, 128, $347-362$. [CrossRef]

20. Rapacz, M.; Ergon, Å.; Höglind, M.; Jørgensen, M.; Jurczyk, B.; Østrem, L.; Rognli, O.A.; Tronsmo, A.M. Overwintering of herbaceous plants in a changing climate. Still more questions than answers. Plant Sci. 2014, 225, 34-44. [CrossRef] [PubMed]

21. Andrews, C.J.; Gudleifsson, B.E. A comparison of cold hardiness and ice encasement tolerance of timothy grass and winter wheat. Can. J. Plant Sci. 1983, 63, 429-435. [CrossRef]

22. Årsvoll, K. Effects of hardening, plant age, and development in Phleum pratense and Festuca pratensis on resistance to snow mould fungi. Sci. Rep. Agric. Univ. Nor. 1977, 56, 1-14.

23. Tronsmo, A.M. Predisposing effects of low temperature on resistance to winter stress factors in grasses. Acta Agric. Scand. 1983, 34, 210-220. [CrossRef]

24. Stocker, T.F.; Qin, D.; Plattner, G.-K.; Alexander, L.V.; Allen, S.K.; Bindoff, N.L.; Bréon, F.-M.; Church, J.A.; Cubasch, U.; Emori, S.; et al. Technical summary. In Climate Change 2013: The Physical Science Basis. Contribution of Working Group I to the Fifth Assessment Report of the Intergovernmental Panel on Climate Change; Stocker, T.F., Qin, D., Plattner, K.-G., Tignor, M., Allen, S.K., Boschung, J., Nauels, A., Xia, Y., Bex, V., Midgley, P.M., Eds.; Cambridge University Press: Cambridge, UK; New York, NY, USA, 2013.

25. Kirtman, B.; Power, S.B.; Adedoyin, J.A.; Boer, G.J.; Bojariu, R.; Camilloni, I.; Doblas-Reyes, F.J.; Fiore, A.M.; Kimoto, M.; Meehl, G.A.; et al. Near-term climate change: Projections and predictability. In Climate Change 2013: The Physical Science Basis. Contribution of Working Group I to the Fifth Assessment Report of the Intergovernmental Panel on Climate Change; Stocker, T.F., Qin, D., Plattner, K.-G., Tignor, M., Allen, S.K., Boschung, J., Nauels, A., Xia, Y., Bex, V., Midgley, P.M., Eds.; Cambridge University Press: Cambridge, UK; New York, NY, USA, 2013.

26. Uleberg, E.; Hanssen-Bauer, I.; van Oort, B.; Dalmannsdóttir, S. Impact of climate change on agriculture in Northern Norway and potential strategies for adaptation. Clim. Chang. 2014, 122, 27-39. [CrossRef]

27. Virkajärvi, P.; Rinne, M.; Mononen, J.; Niskanen, O.; Järvenranta, K.; Sairanen, A. Dairy production systems in Finland. Grassl. Sci. Eur. 2015, 20, 51-66.

28. Lawrence, T.; Cooper, J.P.; Breese, E.L. Cold tolerance and winter hardiness in Lolium perenne: II. Influence of light and temperature during growth and hardening. J. Agric. Sci. 1973, 80, 341-348. [CrossRef]

29. Nakajima, T.; Abe, J. Environmental factors affecting expression of resistance to pink snow mold caused by Microdochium nivale in winter wheat. Can. J. Bot. 1996, 74, 1783-1788. [CrossRef]

30. Harrison, J.; Tonkinson, C.; Eagles, C.; Foyer, C. Acclimation to freezing temperatures in perennial ryegrass (Lolium perenne). Acta Phys. Plant. 1997, 19, 505-515. [CrossRef]

31. Hanslin, H.M.; Höglind, M. Differences in winter-hardening between phenotypes of Lolium perenne with contrasting water-soluble carbohydrate concentrations. Grass For. Sci. 2009, 64, 187-195. [CrossRef]

32. Østrem, L.; Rapacz, M.; Larsen, A.; Dalmannsdóttir, S.; Jørgensen, M. Influences of growth cessation and photoacclimation on winter survival of non-native Lolium-Festuca grasses in high-latitude regions. Environ. Exp. Bot. 2015, 111, 21-31. [CrossRef]

33. Dalmannsdottir, S.; Jørgensen, M.; Rapacz, M.; Østrem, L.; Larsen, A.; Rognli, O.A. Cold acclimation in warmer extended autumns impairs freezing tolerance of perennial ryegrass (Lolium perenne L.) and timothy (Phleum pratense L.). Physiol. Plant. 2017, in press. [CrossRef] [PubMed]

34. Kurepin, L.V.; Dahal, K.P.; Savitch, L.V.; Singh, J.; Bode, R.; Ivanov, A.G.; Hurry, V.; Hüner, N.P. Role of CBFs as integrators of chloroplast redox, phytochrome and plant hormone signaling during cold acclimation. Int. J. Mol. Sci. 2013, 14, 12729-12763. [CrossRef] [PubMed]

35. Kovi, M.R.; Ergon, Å.; Rognli, O.A. Freezing tolerance recisited-effects of variable temperatures on gene regulation in temperate grasses and legumes. Curr. Opin. Plant Biol. 2016, 33, 140-146. [CrossRef] [PubMed]

36. Gray, G.R.; Chauvin, L.P.; Sarhan, F.; Hüner, N.P.A. Cold acclimation and freezing tolerance (a complex interaction of light and temperature). Plant Physiol. 1997, 114, 467-474. [CrossRef] [PubMed]

37. Hüner, N.P.A.; Öquist, G.; Sarhan, F. Energy balance and acclimation to light and cold. Trends Plant Sci. 1998, 3, 224-230. [CrossRef] 
38. Ensminger, I.; Busch, F.; Hüner, N.P.A. Photostasis and cold acclimation: Sensing low temperature through photosynthesis. Physiol. Plant. 2006, 126, 28-44. [CrossRef]

39. Wilson, K.E.; Ivanov, A.G.; Öquist, G.; Grodzinski, B.; Sarhan, F.; Hüner, N.P.A. Energy balance, organellar redox status, and acclimation to environmental stress. Can. J. Bot. 2006, 84, 1355-1370. [CrossRef]

40. Sandve, S.R.; Kosmala, A.; Rudi, H.; Fjellheim, S.; Rapacz, M.; Yamada, T.; Rognli, O.A. Molecular mechanisms underlying frost tolerance in perennial grasses adapted to cold climates. Plant Sci. 2011, 80, 69-77. [CrossRef] [PubMed]

41. Franklin, K.A.; Whitlam, G.C. Light-quality regulation of freezing tolerance in Arabidopsis thaliana. Nat. Genet. 2007, 39, 1410-1413. [CrossRef] [PubMed]

42. Kinmonth-Schultz, H.A.; Golembeski, G.S.; Imaizumi, T. Circadian clock-regulated physiological outputs: Dynamic responses in nature. Semin. Cell Dev. Biol. 2013, 24, 407-413. [CrossRef] [PubMed]

43. Franklin, K.A.; Toledo-Ortiz, G.; Pyott, D.E.; Halliday, K.J. Interaction of light and temperature signalling. J. Exp. Bot. 2014, 65, 2859-2871. [CrossRef] [PubMed]

44. Novák, A.; Boldizsár, Á.; Ádám, É.; Kozma-Bognár, L.; Majláth, I.; Båga, M.; Tóth, B.; Chibbar, R.; Galiba, G. Light-quality and temperature-dependent CBF14 gene expression modulates freezing tolerance in cereals. J. Exp. Bot. 2016, 67, 1285-1295. [CrossRef] [PubMed]

45. Castonguay, Y.; Laberge, S.; Brummer, E.C.; Volenec, J.J. Alfalfa winter hardiness: A research retrospective and integrated perspective. Adv. Agron. 2006, 90, 203-265.

46. Brummer, E.C.; Shah, M.M.; Luth, L. Reexamining the relationship between fall dormancy and winter hardiness in alfalfa. Crop Sci. 2000, 40, 971-977. [CrossRef]

47. Li, X.; Alarcon-Zuniga, B.; Kang, J.; Tahir, M.H.N.; Jiang, Q.; Wei, Y.; Reyno, R.; Robins, J.G.; Brummer, E.C. Mapping fall dormancy and winter injury in tetraploid alfalfa. Crop Sci. 2005, 55, 1995-2011. [CrossRef]

48. Winfield, M.O.; Lu, C.; Wilson, I.D.; Coghill, J.A.; Edwards, K.J. Plant responses to cold: Transcriptome analysis of wheat. Plant Biotechnol. J. 2010, 8, 749-771. [CrossRef] [PubMed]

49. Bode, R.; Ivanov, A.G.; Hüner, N.P.A. Global transcriptome analyses provide evidence that chloroplast redox state contributes to intracellular as well as long-distance signalling in response to stress and acclimation in Arabidopsis. Photosynth. Res. 2016, 128, 287-312. [CrossRef] [PubMed]

50. Ndong, C.; Danyluk, J.; Hüner, N.P.A.; Sarhan, F. Survey of gene expression in winter rye during changes in growth temperature, irradiance or excitation pressure. Plant Mol. Biol. 2001, 45, 691-703. [CrossRef] [PubMed]

51. Dal Bosco, C.; Busconi, M.; Govoni, C.; Baldi, P.; Stanca, A.M.; Crosatti, C.; Bassi, R.; Cattivelli, L. cor Gene expression in barley mutants affected in chloroplast development and photosynthetic electron transport. Plant Physiol. 2003, 131, 793-802. [CrossRef] [PubMed]

52. Crosatti, C.; Rizza, F.; Badeck, F.W.; Mazzucotelli, E.; Cattivelli, L. Harden the chloroplast to protect the plant. Physiol. Plant. 2013, 147, 55-63. [CrossRef] [PubMed]

53. Rapacz, M. The effects of day and night temperatures during early growth of winter rape seedlings on their morphology and cold acclimation responses. Acta Physiol. Plant. 1998, 20, 67-72. [CrossRef]

54. McClung, C.R.; Davies, S.J. Ambient Thermometers in Plants: From Physiological Outputs towards Mechanisms of Thermal Sensing. Curr. Biol. 2010, 20, R1086-R1092. [CrossRef] [PubMed]

55. Pocock, T.H.; Hurry, V.; Savitch, L.V.; Huner, N.P.A. Susceptibility to low-temperature photoinhibition and the acquisition of freezing tolerance in winter and spring wheat: The role of growth temperature and irradiance. Physiol. Plant. 2001, 113, 499-506. [CrossRef]

56. Dahlal, K.; Kane, K.; Gadapati, W.; Webb, E.; Savitch, L.V.; Singh, J.; Sharma, P.; Sarhan, F.; Longstaffe, F.J.; Grodzinski, B.; et al. The effects of phenotypic plasticity on photosynthetic performance in winter rye, winter wheat and Brassica napus. Physiol. Plant. 2012, 144, 169-188. [CrossRef] [PubMed]

57. Dahlal, K.; Kane, K.; Sarhan, F.; Grodzinski, B.; Hüner, N.P.A. Cold acclimation inhibits $\mathrm{CO}_{2}$-dependent stimulation of photosynthesis in spring wheat and spring rye. Botany 2012, 90, 433-444. [CrossRef]

58. Rapacz, M.; Gasior, D.; Zwierzykowski, Z.; Lesniewska-Bocianowska, A.; Humphreys, M.W.; Gay, A.P. Changes in cold tolerance and the mechanisms of acclimation of photosystem II to cold hardening generated by anther culture of Festuca pratensis $\times$ Lolium multiflorum cultivars. New Phytol. 2004, 162, 105-114. [CrossRef] 
59. Humphreys, M.W.; Gasior, D.; Lesniewska-Bocianowska, A.; Zwierzykowski, Z.; Rapacz, M. Androgenesis as a means of dissecting complex genetic and physiological controls: Selecting useful gene combinations for breeding freezing tolerant grasses. Euphytica 2007, 158, 337-345. [CrossRef]

60. Dalmannsdóttir, S.; Rapacz, M.; Jørgensen, M.; Østrem, L.; Larsen, A.; Rødven, R.; Rognli, O.A. Temperature before cold acclimation affects cold tolerance and photoacclimation in timothy (Phleum pratense L.), perennial ryegrass (Lolium perenne L.) and red clover (Trifolium pratense L.). J. Agron. Crop Sci. 2016, 202, 320-330. [CrossRef]

61. Kosmala, A.; Bocian, A.; Rapacz, M.; Jurczyk, B.; Zwierzykowski, Z. Identification of leaf proteins differentially accumulated during cold acclimation between Festuca pratensis plants with distinct levels of frost tolerance. J. Exp. Bot. 2009, 60, 3595-3609. [CrossRef] [PubMed]

62. Pollock, C.J.; Jones, T. Seasonal patterns of fructan metabolism in forage grasses. New Phytol. 1979, 83, 9-15. [CrossRef]

63. Dionne, J.; Castonguay, Y.; Nadeau, P.; Desjardins, Y. Freezing tolerance and carbohydrate changes during cold acclimation of green-type annual bluegrass (Poa annua L.) ecotypes. Crop Sci. 2001, 41, 443-451. [CrossRef]

64. Østrem, L.; Rapacz, M.; Jørgensen, M.; Höglind, M. Effect of developmental stage on carbohydrate accumulation patterns during winter of timothy and perennial ryegrass. Acta Agric. Scand. Sect. B Soil Plant Sci. 2011, 61, 153-163. [CrossRef]

65. Yoshida, M.; Abe, J.; Moiyama, M.; Kuwabara, T. Carbohydrate levels among winter wheat cultivars varying in freezing tolerance and snow mold resistance during autumn and winter. Physiol. Plant. 1998, 103, 8-16. [CrossRef]

66. Sanada, Y.; Takai, T.; Yamada, T. Ecotypic variation of water-soluble carbohydrate concentration and winter hardiness in cocksfoot (Dactylis glomerata L.). Euphytica 2007, 153, 267-280. [CrossRef]

67. Abeynayake, S.W.; Byrne, S.; Nagy, I.; Jonavičien, K.; Etzerodt, T.P.; Boelt, B.; Asp, T. Changes in Lolium perenne transcriptome during cold acclimation in two genotypes adapted to different climatic conditions. BMC Plant Biol. 2015, 15, 250. [CrossRef] [PubMed]

68. Obrist, D.; Arnone , J.A., III; Körner, C. In situ effects of elevated atmospheric $\mathrm{CO}_{2}$ on leaf freezing resistance and carbohydrates in a native temperate grassland. Ann. Bot. 2001, 87, 839-844. [CrossRef]

69. Jurczyk, B.; Rapacz, M.; Krepski, T. Short-term growth of meadow fescue with atmospheric $\mathrm{CO}_{2}$ enrichment decreases freezing tolerance, modifies photosynthetic apparatus performance and changes the expression of some genes during cold acclimation. Acta Physiol. Plant. 2013, 35, 1543-1554. [CrossRef]

70. Østrem, L.; Rapacz, M.; Jørgensen, M.; Höglind, M. Impact of frost and plant age on compensatory growth in timothy and perennial ryegrass during winter. Grass For. Sci. 2010, 65, 15-22. [CrossRef]

71. Eagles, C.F. Apparent photosynthesis and respiration in populations of Lolium perenne from contrasting climatic regions. Nature 1967, 215, 100-101. [CrossRef]

72. Skinner, H. Winter carbon dioxide fluxes in humid-temperate pastures. Agric. For. Meteorol. 2007, 144, $32-43$. [CrossRef]

73. Van Oijen, M.; Höglind, M. Toward a Bayesian procedure for using process-based models in plant breeding, with application to ideotype design. Euphytica 2016, 207, 627-643. [CrossRef]

74. Wingler, A. Comparison of signaling interactions determining annual and perennial plant growth in response to low temperature. Front. Plant Sci. 2014, 5, 794. [CrossRef] [PubMed]

75. Hüner, N.P.A.; Dahal, K.; Bode, R.; Kurepin, L.V.; Ivanov, A.G. Photosynthetic acclimation, vernalization, crop productivity and "the grand design of photosynthesis". J. Plant Physiol. 2016, 203, 29-43. [CrossRef] [PubMed]

76. Hay, R.K.M. The influence of photoperiod on the dry matter production of grasses and cereals. New Phytol. 1990, 116, 233-254. [CrossRef]

77. Solhaug, K.A. Long day stimulation of dry matter production in Poa alpina along a longitudinal gradient in Norway. Holarct. Ecol. 1991, 14, 161-168.

78. Wu, Z.; Skjelvåg, A.O.; Baadshaug, O.H. Quantification of photoperiodic effects on growth of Phleum pratense. Ann. Bot. 2004, 94, 535-543. [CrossRef] [PubMed]

79. Ryle, G.J.A. Effects of photoperiod in the glasshouse on the growth of leaves and tillers in three perennial grasses. Ann. Appl. Biol. 1966, 57, 257-268. [CrossRef] 
80. Aamlid, T.S. Effects of temperature and photoperiod on growth and development of tillers and rhizomes in Poa pratensis L. ecotypes. Ann. Bot. 1992, 69, 289-296. [CrossRef]

81. Kebrom, T.H.; Brutnell, T.P. The molecular analysis of the shade avoidance syndrome in the grasses has begun. J. Exp. Bot. 2007, 58, 3079-3089. [CrossRef] [PubMed]

82. Galiba, G.; Vágújfalvi, A.; Li, C.; Soltesz, A.; Dubcovsky, J. Regulatory genes involved in the determination of frost tolerance in temperate cereals. Plant Sci. 2009, 176, 12-19. [CrossRef]

83. Skinner, J.S.; von Zitzewitz, J.; Szücs, P.; Marquez-Cedillo, L.; Filichkin, T.; Amundsen, K.; Stockinger, E.J.; Thomashow, M.F.; Chen, T.H.H.; Hayes, P.M. Structural, functional, and phylogenetic characterization of a large CBF gene family in barley. Plant Mol. Biol. 2005, 59, 533-551. [CrossRef] [PubMed]

84. Badawi, M.; Danyluk, J. The CBF gene family in hexaploid wheat and its relationship to the phylogenetic complexity of cereal CBFs. Mol. Genet. Genom. 2007, 277, 533-554. [CrossRef] [PubMed]

85. Marozsán-Tóth, Z.; Vashegyi, I.; Galiba, G.; Tóth, B. The cold response of CBF genes in barley is regulated by distinct signaling mechanisms. J. Plant Physiol. 2015, 181, 42-49. [CrossRef] [PubMed]

86. Alm, V.; Busso, C.S.; Ergon, Å.; Rudi, H.; Larsen, A.; Humphreys, M.W.; Rognli, O.A. QTL analyses and comparative genetic mapping of frost tolerance, winter survival and drought tolerance in meadow fescue (Festuca pratensis Huds.). Theor. Appl. Genet. 2011, 123, 369-382. [CrossRef] [PubMed]

87. Xiong, Y.; Fei, S.-Z.; Arora, R.; Brummer, E.C.; Barker, R.E.; Jung, G.; Warnke, S.E. Identification of quantitative trait loci controlling winter hardiness in an annual-Perennial ryegrass interspecific hybrid population. Mol. Breed. 2007, 19, 125-136. [CrossRef]

88. Ryu, J.Y.; Hong, S.-Y.; Jo, S.-H.; Woo, J.-C.; Lee, S.; Park, C.-M. Molecular and functional characterization of cold-responsive C-repeat binding factors from Brachypodium distachyon. BMC Plant Biol. 2015, 14, 15. [CrossRef] [PubMed]

89. Fricano, A.; Rizza, F.; Faccioli, P.; Pagani, D.; Pavan, P.; Stella, A.; Rossini, L.; PiVanelli, P.; Cattivelli, L. Genetic variants of Hvcbf14 are statistically associated with frost tolerance in a European germplasm collection of Hordeum vulgare. Theor. Appl. Genet. 2009, 119, 1335-1348. [CrossRef] [PubMed]

90. Zhu, J.; Pearce, S.; Burke, A.; See, D.R.; Skinner, D.Z.; Dubcovsky, J.; Garland-Campbell, K. Copy number and haplotype variation at the $V R N-A 1$ and central $F R-A 2$ loci are associated with frost tolerance in hexaploid wheat. Theor. Appl. Genet. 2014, 127, 1183-1197. [CrossRef] [PubMed]

91. Sieber, A.-N.; Longin, C.F.H.; Leiser, W.L.; Würschum, T. Copy number variation of CBF-A14 at the $F r-A 2$ locus determines frost tolerance in winter durum wheat. Theor. Appl. Genet. 2016, 129, 1087-1097. [CrossRef] [PubMed]

92. Frankia, E.; Morcia, C.; Pasquariello, M.; Mazzamurro, V.; Milc, J.A.; Rizza, F.; Terzi, V.; Pecchioni, N. Copy number variation at the $H v C B F 4-H v C B F 2$ genomic segment is a major component of frost resistance in barley. Plant Mol. Biol. 2016, 92, 161-175. [CrossRef] [PubMed]

93. Svensson, J.T.; Crosatti, C.; Campoli, C.; Bassi, R.; Stanca, A.M.; Close, T.J.; Cattivelli, L. Transcriptome analysis of cold acclimation in barley Albina and Xantha mutants. Plant Physiol. 2006, 141, 257-270. [CrossRef] [PubMed]

94. Jurczyk, B.; Rapacz, M.; Budzisz, K.; Barcik, W.; Sasal, M. The effects of cold, light and time of day during low-temperature shift on the expression of CBF6, FpCor14b and LOS2 in Festuca pratensis. Plant Sci. 2012, 183, 143-148. [CrossRef] [PubMed]

95. Archard, P.; Gong, F.; Cheminant, S.; Alioua, M.; Hedden, P.; Genschik, P. The cold-inducible CBF1 factor-dependent signaling pathway modulates the accumulation of the growth-repressing DELLA proteins via its effect on gibberellin metabolism. Plant Cell 2008, 20, 2117-2129. [CrossRef] [PubMed]

96. Achard, P.; Renou, J.P.; Berthome, R.; Harberd, N.P.; Genschik, P. Plant DELLAs restrain growth and promote survival of adversity by reducing the levels of reactive oxygen species. Curr. Biol. 2008, 18, 656-660. [CrossRef] [PubMed]

97. Savitch, L.V.; Allard, G.; Seki, M.; Robert, L.S.; Tinker, N.A.; Hüner, N.P.A.; Shinozaki, K.; Singh, J. The effect of over-expression of two Brassica CBF/DREB1-liketranscription factors on photosynthetic capacity and freezing tolerance in Brassica napus. Plant Cell Physiol. 2005, 46, 1525-1539. [CrossRef] [PubMed]

98. Dahal, K.; Gadapati, W.; Savitch, L.; Singh, J.; Hüner, N.P.A. Cold acclimation and BnCBF17-over-expression enhance photosynthetic performance and energy conversion efficiency during long-term growth of Brassica napus under elevated $\mathrm{CO}_{2}$ conditions. Planta 2012, 236, 1639-1652. [CrossRef] [PubMed] 
99. Tronsmo, A.M. Effects of dehardening on resistance to freezing and to infection by Typhula ishikariensis in Phleum pratense. Acta Agric. Scand. 1985, 35, 113-116. [CrossRef]

100. Gay, A.P.; Eagles, C.F. Quantitative analysis of cold hardening and dehardening in Lolium. Ann. Bot. 1991, 67, 339-345.

101. Tompkins, D.K.; Ross, J.B.; Moroz, D.L. Dehardening of annual bluegrass and creeping bentgrass during late winter and early spring. Agron. J. 2000, 92, 5-9. [CrossRef]

102. Jørgensen, M.; Østrem, L.; Höglind, M. De-hardening in contrasting cultivars of timothy and perennial ryegrass during winter and spring. Grass For. Sci. 2010, 65, 38-48. [CrossRef]

103. Espevig, T.; Höglind, M.; Aamlid, T.S. Dehardening resistance of six turfgrasses used on golf greens. Environ. Exp. Bot. 2014, 106, 082-188. [CrossRef]

104. Hoffmann, L.; DaCosta, M.; Ebdon, J.S. Examination of cold deacclimation sensitivity of annual bluegrass and creeping bentgrass. Crop Sci. 2014, 54, 413-420. [CrossRef]

105. Ergon, Å.; Melby, T.I.; Höglind, M.; Rognli, O.A. Vernalization requirement and the chromosomal VRN1-region can affect freezing tolerance and expression of cold-regulated genes in Festuca pratensis. Front. Plant Sci. 2016, 7, 207. [CrossRef] [PubMed]

106. Fowler, D.B.; Chauvin, L.P.; Limin, A.E.; Sarhan, F. The regulatory role of vernalization in the expression of low-temperature-induced genes in wheat and rye. Theor. Appl. Genet. 1996, 93, 554-559. [CrossRef] [PubMed]

107. Limin, A.E.; Fowler, D.B. Low-temperature tolerance and genetic potential in wheat (Triticum aestivum L.): response to photoperiod, vernalization, and plant development. Planta 2006, 224, 360-366. [CrossRef] [PubMed]

108. Laudencia-Chingcuanco, D.; Ganeshan, S.; You, F.; Fowler, B.; Chibbar, R.; Anderson, O. Genome-wide gene expression analysis supports a developmental model of low temperature tolerance gene regulation in wheat (Triticum aestivum L.). BMC Genom. 2011, 12, 99. [CrossRef] [PubMed]

109. Mahfoozi, S.; Limin, A.E.; Fowler, D.B. Influence of vernalization and photoperiod responses on cold hardiness in winter cereals. Crop Sci. 2001, 41, 1006-1011. [CrossRef]

110. Mahfoozi, S.; Limin, A.E.; Ahakpaz, F.; Roustaii, M.; Ketata, H.; Fowler, D.B. Regulation of low-temperature tolerance in barley under field conditions in northwest Iran. Can. J. Plant Sci. 2005, 85, 587-592. [CrossRef]

111. Mahfoozi, S.; Limin, A.E.; Ahakpaz, F.; Fowler, D.B. Phenological development and expression of freezing resistance in spring and winter wheat under field conditions in northwest Iran. Field Crop Res. 2006, 97, 182-187. [CrossRef]

112. Dhillon, T.; Pearce, S.P.; Stockinger, E.J.; Distelfeld, A.; Li, C.; Knox, A.K.; Vashegyi, I.; Vágújfalvi, A.; Galiba, G.; Dubcovsky, J. Regulation of freezing tolerance and flowering in temperate cereals: The VRN-1 connection. Plant Physiol. 2010, 153, 1846-1858. [CrossRef] [PubMed]

113. Mahfoozi, S.; Limin, A.E.; Fowler, D.B. Developmental regulation of low-temperature tolerance in winter wheat. Ann. Bot. 2001, 87, 751-757. [CrossRef]

114. Trischuk, G.; Schilling, B.S.; Low, N.H.; Gray, G.R.; Gusta, L.V. Cold acclimation, de-acclimation and re-acclimation of spring canola, winter canola and winter wheat: the role of carbohydrates, cold-induced stress proteins and vernalization. Environ. Exp. Bot. 2014, 106, 156-163. [CrossRef]

115. Stapleton, J.; Jones, M.B. Effects of vernalization on the subsequent rates of leaf extension and photosynthesis of perennial ryegrass (Lolium perenne L.). Grass For. Sci. 1987, 42, 27-31. [CrossRef]

116. Trevaskis, B. The central role of the VERNALIZATION 1 gene in the vernalization response of cereals. Funct. Plant Biol. 2010, 37, 479-487. [CrossRef]

117. Fjellheim, S.; Boden, S.; Trevaskis, B. The role of seasonal flowering responses in adaptation of grasses to temperate climates. Front. Plant Sci. 2014, 5, 431. [CrossRef] [PubMed]

118. Cuesta-Marcos, A.; Muñoz-Amatriaín, M.; Filichkin, T.; Karsai, I.; Trevaskis, B.; Yasuda, S.; Hayes, P.; Sato, K. The relationships between development and low temperature tolerance in barley near isogenic lines differing for flowering behavior. Plant Cell Physiol. 2015, 56, 2312-2324. [CrossRef] [PubMed]

119. Deng, W.; Casao, M.C.; Wang, P.; Sato, K.; Hayes, P.M.; Finnegan, E.J.; Trevaskis, B. Direct links between vernalization response and other key traits of cereal crops. Nat. Commun. 2015, 6, 5882. [CrossRef] [PubMed]

120. Oliver, S.N.; Deng, W.; Casao, M.C.; Trevaskis, B. Low temperatures induce rapid changes in chromatin state and transcript levels of the cereal VERNALIZATION1 gene. J. Exp. Bot. 2013, 64, 2413-2422. [CrossRef] [PubMed] 
121. Greenup, A.G.; Sasani, S.; Oliver, S.N.; Walford, S.A.; Millar, A.A.; Trevaskis, B. Transcriptome analysis of the vernalization response in barley (Hordeum vulgare) seedlings. PLoS ONE 2011, 6, e17900. [CrossRef] [PubMed]

122. Alonso-Peral, M.M.; Oliver, S.N.; Casao, M.C.; Greenup, A.A.; Trevaskis, B. The promoter of the cereal VERNALIZATION1 gene is sufficient for transcriptional induction by prolonged cold. PLOS ONE 2011, 6, e29456. [CrossRef] [PubMed]

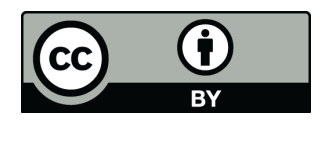

(c) 2017 by the author. Licensee MDPI, Basel, Switzerland. This article is an open access article distributed under the terms and conditions of the Creative Commons Attribution (CC BY) license (http://creativecommons.org/licenses/by/4.0/). 